\title{
PEMUTIHAN PULP TANDAN KOSONG SAWIT DENGAN PROSES-PROSES KIMIA RAMAH LINGKUNGAN
}

\author{
H Susanto ${ }^{*}$
}

\begin{abstract}
Abstrak
Beberapa proses pemutihan ramah lingkungan telah diuji-coba sebagai kelanjutan pengembangan proses pemanfaatan tandan kosong sawit (TKS). Pulp TKS dengan bilangan Kappa 33 sebagai bahan baku pemutihan disiapkan dengan proses kraft konvensional dan proses etanol yang ramah lingkungan. Pemutihan dilakukan dengan proses $\mathrm{ODEODnD}$ yang bebas $\mathrm{Cl}_{2}$ (elemental chlorine free), serta proses PP dan proses OPOP yang tanpa khlor sama sekali (totally chlorine free). Proses konvensional CEDED dengan $\mathrm{Cl}_{2}$ digunakan sebagai pembanding. Pulp putih TKS umumnya memiliki kekuatan mirip dengan pulp putih kayudaun: indeks sobek $6,5-8,5 \mathrm{Nm}^{2} / \mathrm{kg}$, indeks retak 3,5-3,7 $\mathrm{Nm}^{2} / \mathrm{kg}$, dan indeks tarik sekitar $34 \mathrm{Nm} / \mathrm{kg}$. Sayangnya, pemutihan dengan proses PP dan OPOP menghasilkan pulp putih dengaan derajat putih hanya sekitar $41 \% G E$. Pemutihan dengan proses $O D E O D n D$ atau proses CEDED menghasilkan pulp dengan derajat putih $80-84 \%$ GE. Derajat putih pulp TKS dari dua proses terakhir ini mirip dengan pulp putih kayudaun (81\%GE). Pulp TKS dengan sifat-sifat semacam ini dapat dijadikan bahan baku kertas koran yang memiliki spesifikasi: derajat putih $57 \%$, indeks sobek $4,35 \mathrm{Nm}^{2} / \mathrm{kg}$ dan indeks tarik $21 \mathrm{Nm} / \mathrm{g}$.
\end{abstract}

Kata kunci: limbah organik padat, pulping, pemutihan ramah lingkungan

\section{Pendahuluan}

Indonesia merupakan negara penghasil minyak sawit mentah atau CPO (crude palm oil) terbesar kedua setelah Malaysia. Peningkatan produksi CPO di Indonesia tentu akan meningkatkan produksi limbah padat tandan kosong sawit (TKS) dengan massa yang kira-kira sama. Pemanfaatan TKS sebagai bahan baku pulp mungkin merupakan salah satu alternatif untuk penanganan limbah padat yang sekaligus memberi nilai tambah bagi industri minyak sawit dan substitusi bahan baku pulp.

Penanganan TKS sebagai bahan baku pulp telah banyak dilakukan oleh para peneliti dari berbagai lembaga penelitian di Indonesia. Pulping (proses pemasakan untuk menghasilkan pulp) umumnya dilaksanakan dengan proses konvensional soda atau proses kraft. Proses etanol (ethanosolvpulping), walaupun masih dalam taraf pengembangan, diperkirakan cocok untuk diterapkan pada industri pulp kecil sesuai dengan ketersediaan TKS pada suatu pabrik CPO ( $8-15$ ton TKS/jam). Untuk sebuah pabrik pulp dengan kapasitas produksi kecil, proses etanol menawarkan keunggulan terutama tidak memerlukan unit pemulihan bahan kimia (chemical recovery) serumit proses kraft. Di samping itu, proses etanol juga menawarkan proses ramah lingkungan karena tidak menggunakan senyawa belerang dan dapat dikembangkan untuk menghasilkan furfural sebagai produk samping [Petty, 1989]. Beberapa hasil penelitian pembuatan pulp dari TKS dengan proses etanol telah disajikan dalam makalah sebelumnya [Susanto, 1999: Susanto dan Pratiwi, 1999].
Sebagai kelanjutan program penelitian sebelumnya, penelitian tentang pemutihan pulp TKS dilaporkan dalam makalah. Penelitian ini ditujukan untuk mengkaji efektivitas tiga proses pemutihan ramah lingkungan. Efektivitas proses pemutihan dievaluasi atas dasar: derajat putih dan ketahanan fisik pulp putih.

\section{Serat selulosa TKS}

Secara morfologis, serat selulosa TKS memiliki panjang rata-rata $0,74 \mathrm{~mm}$, diameter luar $10,14 \mu \mathrm{m}$, dan tebal dinding $3,52 \mu \mathrm{m}$. Serat TKS termasuk ke dalam kelompok serat pendek dengan diameter sedang. TKS umumnya mengandung sekitar $38 \%$ selulosa, $27 \%$ hemiselulosa dan $18 \%$ lignin.

Proses pembuatan pulp

Sekitar $90 \%$ pembuatan pulp secara kimia didominasi oleh proses kraft dengan cairan pemasak larutan larutan $\mathrm{NaOH}$ dan $\mathrm{Na}_{2} \mathrm{~S}$ dengan temperatur sekitar $170^{\circ} \mathrm{C}$ dan tekanan sekitar 10 bar. Pada skala komersial, proses $\mathrm{NaOH}$ recovery merupakan faktor penentu ekonomi.

Pembuatan pulp dengan proses etanol adalah pelarutan lignin ke dalam etanol dengan bantuan sedikit $\mathrm{NaOH}$. Proses ini masih dalam taraf pengembangan dan diuji-coba pra-komersial dengan kapasitas 15 ton/hari oleh Repap Technology di Kanada (Alcell Process, [Petty, 1989]). Temperatur proses etanol kira-kira $190^{\circ} \mathrm{C}$ (tekanan 20 bar).

Pemutihan pulp

Pemutihan umumnya dilakukan dengan beberapa tahapan proses untuk mencapai derajat

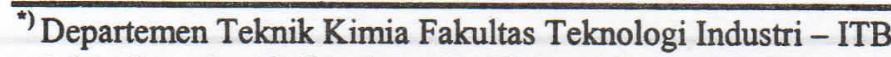

Jalan Ganesha 10, Bandung, email: herri@che.itb.ac.id 
putih tinggi tanpa menimbulkan banyak degradasi serat atau penurunan kekuatan pulp. Pemutihan dengan khlor yang menghasilkan pulp putih dengan kualitas baik, ternyata menimbulkan senyawa organik-khlor beracun. Karena itu proses pemutihan ramah lingkungan perlu dikembangkan.

Pada prinsipnya, pemilihan bahan kimia untuk proses pemutihan didasarkan pada faktor-faktor berikut ini [Grace, Leopold dan Malcolm, 1989]:

- harga bahan kimia (dari yang termurah): $\mathbf{O}$ (dengan menggunakan $\mathrm{O}_{2}$ ) $>\mathbf{H}$ (hipokhlorit) $>\mathbf{C}$ (khlor, $\mathrm{Cl}_{2}$ ) $>$ D (khlor dioksida, $\left.\mathrm{ClO}_{2}\right)>\mathbf{P}$ (peroksida) $>\mathbf{Z}$ (ozon)

- $\quad$ selektivitas delignifikasi (dari yang terkuat): $\mathbf{D}>$ $\mathbf{C}>\mathbf{O}>\mathbf{Z}$

- derajat putih (dari yang hasilnya terbaik): $\mathbf{C}>$ $(\mathrm{D}, \mathbf{P})>\mathbf{H}$.

\section{Metodologi}

Penelitian ini mencakup tiga tahap percobaan (lihat Gambar 1): pulping, pemutihan dan pengujian sifat pulp putih. Pulp hasil proses etanol dan proses kraft (lihat Tabel 1) diputihkan dengan proses-proses berikut ini. a. Proses CEDED konvensional (lihat Tabel 2): khlorinasi dengan $\mathrm{Cl}_{2}$, ekstraksi, khlorinasi dengan $\mathrm{ClO}_{2}$, dan ekstraksi, khlorinasi $\left(\mathrm{ClO}_{2}\right)$.

b. Proses ODEoDnD Elemental Chlorine Free ( $E C F$, Tabel 3),: oksidasi (delignifikasi lanjut dengan $\left.\mathrm{O}_{2}\right)$, khlorinasi $\left(\mathrm{ClO}_{2}\right)$, ekstraksi dan oksigenasi $\left(\mathrm{NaOH}\right.$ dan $\left.\mathrm{O}_{2}\right)$, khlorinasi $\left(\mathrm{ClO}_{2}\right.$ dan netralisasi) dan khlorinasi $\left(\mathrm{ClO}_{2}\right)$.

c. Proses PP, Totally Chlorine Free (TCF, Tabel 4): peroksidasi (delignifikasi lanjut dengan $\mathrm{H}_{2} \mathrm{O}_{2}$ ) dan peroksidasi.

d. Proses OPOP (TCF, Tabel 4): oksidasi (delignifikasi lanjut dengan $\mathrm{O}_{2}$ ), peroksidasi, oksidasi, dan peroksidasi.

Pengujian pulp belum putih dan pulp putih meliputi: rendemen (yield), Kappa Number (KN), kandungan $\alpha$-selulosa dalam pulp, viskositas pulp, derajat putih (brigthness), indeks sobek, indeks tarik, dan indeks retak. Pengujian sifat-sifat pulp tersebut dilakukan menurut prosedur SNI (Standard Nasional Indonesia) yang umumnya diadopsi dari TAPPI. Evaluasi kekuatan fisik pulp dilakukan pada derajat giling $40^{\circ} \mathrm{SR}$.

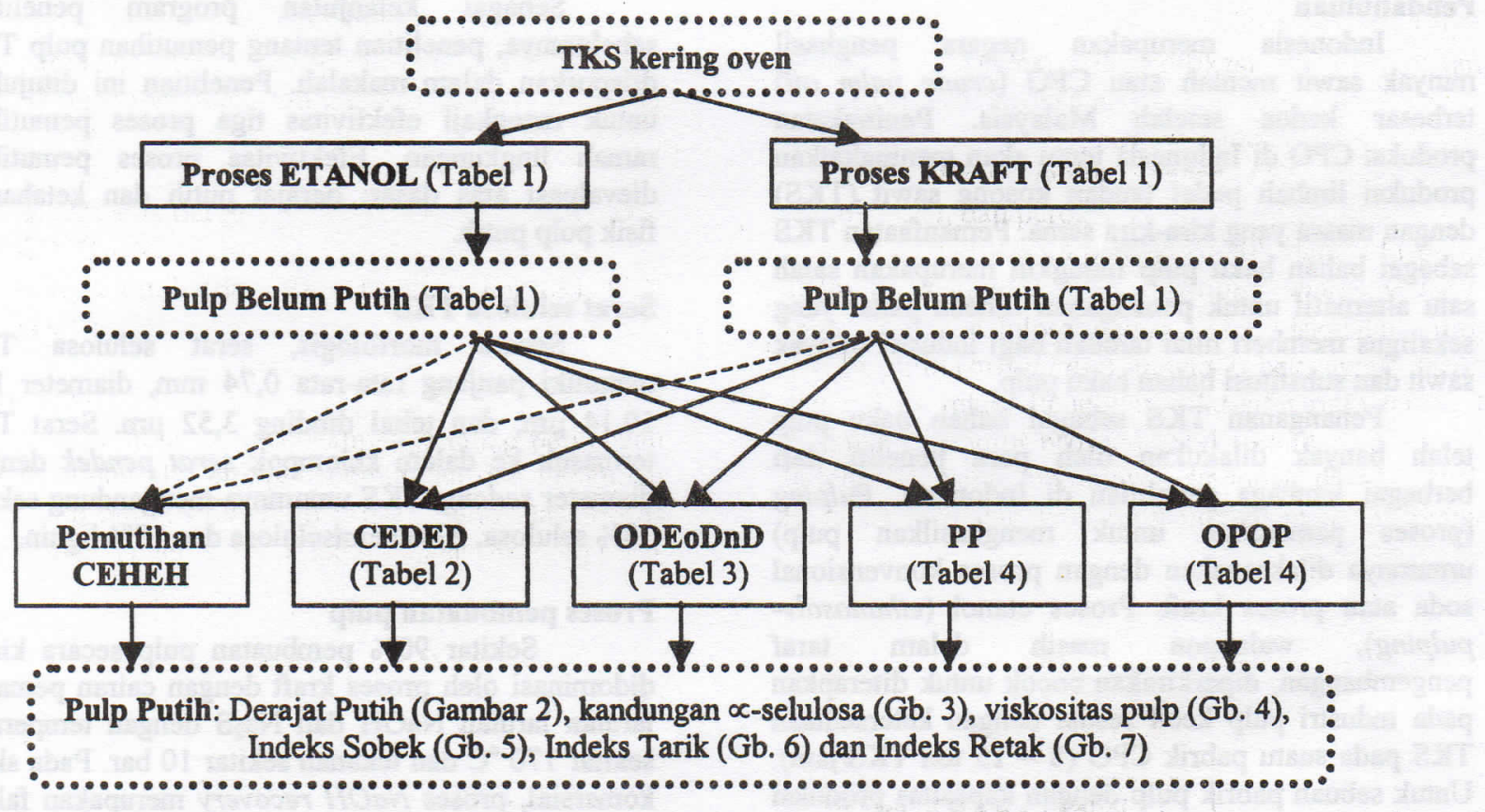

Hasil dan Pembahasan

Penyediaan pulp

Untuk mencapai $\mathrm{KN}$ yang sama, proses etanol memerlukan temperatur pemasakan lebih tinggi dan juga waktu-masak lebih lama daripada proses kraft (Tabel 1). Selanjutnya karena volatility etanol, proses etanol memerlukan tekanan tinggi (sekitar 12 bar pada $170{ }^{\circ} \mathrm{C}$ ). Kondisi proses yang relatif berat ini mungkin menyebabkan proses etanol belum populer sampai saat ini. Tetapi dengan persyaratan dampak lingkungan yang makin ketat,
Gambar 1. Ruang lingkup penelitian

proses etanol diharapkan akan menjadi pilihan yang menarik pada masa mendatang.

\subsection{Kandungan $\alpha$-Selulosa dan Viskositas Pulp Putih}

Kandungan $\alpha$-selulosa semua pulp putih yang diperoleh dari penelitian ini berkisar antara 70 . $75 \%$ (Gambar 2). Dengan kandungan $\alpha$-selulosa ini, kualitas pulp TKS sulit untuk ditingkatkan menjadi dissolving pulp ( $\alpha$-selulosa 90\%). 
Tabel 1. Kondisi proses dan hasil pulping revolving globe digester dengan kapasitas $3 \mathrm{~L}$

\begin{tabular}{|c|c|c|c|c|c|c|c|}
\hline & Pros & Etanol & $\sqrt{6+2}$ & 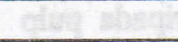 & Pros & Kraft & 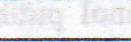 \\
\hline a. perbandir & an caira & $\mathrm{KS}=10$ & & a. perbandin & n caira & $\mathrm{KS}=4 \mathrm{~L}$ & \\
\hline b. konsentr: & etanol & $0 \%$-mass & & b. $\mathrm{Na}_{2} \mathrm{SO}_{3}=$ & $46 \%$ th & KS (Sulf & is $=25 \%)$ \\
\hline c. $\mathrm{NaOH}=$ & thd $\mathrm{T}$ & 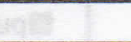 & & c. $\mathrm{NaOH}=1$ & $6 \%$ thd & $\mathrm{KS}(\mathrm{AA}=$ & \\
\hline d. temperat & pemasa & $1=170^{\circ} \mathrm{C}$ & & d. temperatu & semasa & $=150^{\circ} \mathrm{C}$ & \\
\hline e. waktu-tuj & to tem & $=145 \mathrm{mer}$ & & e. waktu-tuj] & to temp & 120 men & \\
\hline f. waktu-ma & $\mathrm{k}($ at te & $=150 \mathrm{~m}$ & & f. waktu-ma & c(at ter & $=60 \mathrm{mn}$ & \\
\hline percobaan & renc & en, $\%$ & Kappa & percobaan & renc & en, $\%$ & Kappa \\
\hline nomor & total & tersaring & number & nomor & total & tersaring & Number \\
\hline 1 & 42,30 & 42,25 & 35,32 & 7 & 47,38 & 47,16 & 31,14 \\
\hline 2 & 45,34 & 44,34 & 34,83 & 8 & 46,68 & 46,58 & 32,64 \\
\hline 3 & 45,75 & 45,70 & 33,60 & 9 & 46,64 & 46,55 & 32,64 \\
\hline 4 & 45,30 & 45,29 & 33,57 & 10 & 46,70 & 46,22 & 30,04 \\
\hline 5 & 46,31 & 46,22 & 33,55 & 11 & 44,41 & 44,23 & 30,73 \\
\hline 6 & 45,90 & 45,78 & 32,39 & 12 & 47,05 & 46,68 & 32,76 \\
\hline rata-rata & 44,58 & 44,57 & 32,90 & rata-rata & 46,37 & 46,14 & 32,30 \\
\hline
\end{tabular}

Tabel 2. Kondisi pemutihan CEDED

\begin{tabular}{|c|c|c|c|c|c|c|}
\hline tahap & $\begin{array}{c}\text { konsistensi } \\
\%\end{array}$ & $\begin{array}{c}\mathrm{NaOH} \\
\left.\%^{1}\right)\end{array}$ & $\begin{array}{c}\mathrm{Cl}_{2} \\
\left.\text { sbg khlor aktif, \% }{ }^{1}\right)\end{array}$ & $\begin{array}{c}\mathrm{ClO}_{2} \\
\left.\%^{1}\right)^{1}\end{array}$ & $\begin{array}{c}\text { temp. } \\
{ }^{\circ} \mathrm{C}\end{array}$ & $\begin{array}{c}\text { waktu } \\
\text { menit }\end{array}$ \\
\hline C & 3,5 & - & 0,$\left.2 ; 0,22 ; 0,24^{2}\right)$ & - & 27 & 60 \\
\hline E & 10 & 1,5 & - & - & 60 & 60 \\
\hline D & 10 & - & - & 1 & 70 & 180 \\
\hline E & 10 & 1 & - & - & 60 & 60 \\
\hline D & 10 & - & - & 0,5 & 70 & 180 \\
\hline
\end{tabular}

1) jumlah bahan kimia dinyatakan sebagai persen terhadap pulp kering oven

${ }^{2}$ ) perkalian faktor ini dengan $K N$ dijadikan persentase bahan kimia terhadap pulp kering oven

Tabel 3. Kondisi pemutihan ODEoDnD

\begin{tabular}{|c|c|c|c|c|c|c|c|c|c|}
\hline tahap & $\begin{array}{c}\text { konsis } \\
\text {-tensi } \\
\%\end{array}$ & $\begin{array}{c}\mathrm{NaOH} \\
\left.\%^{1}\right)\end{array}$ & $\begin{array}{c}\mathrm{ClO}_{2} \\
\text { sbg khlor aktif } \\
\left.\%{ }^{1}\right)\end{array}$ & $\begin{array}{l}\mathrm{ClO}_{2} \\
\left.\%{ }^{1}\right) \\
\end{array}$ & $\begin{array}{c}\mathrm{O}_{2} \\
\mathrm{~atm}\end{array}$ & $\begin{array}{c}\mathrm{MgSO}_{4} . \\
7 \mathrm{H}_{2} \mathrm{O} \\
\% \\
\%\end{array}$ & $\begin{array}{c}\mathrm{H}_{2} \mathrm{SO}_{4} \\
\left.\%^{1}\right) \\
\end{array}$ & $\begin{array}{c}\text { temp. } \\
{ }^{\circ} \mathrm{C} \\
\end{array}$ & $\begin{array}{l}\text { waktu } \\
\text { menit }\end{array}$ \\
\hline 0 & 10 & 1 & - & - & 6 & 0,5 & $=$ & 100 & 60 \\
\hline D & 10 & - & 0,$\left.2 ; 0,22 ; 0,24^{2}\right)$ & - & - & - & 0,4 & 70 & 60 \\
\hline Eo & 10 & 2 & - & - & 6 & - & - & 70 & 60 \\
\hline D & 10 & 0,35 & $=$ & 1 & - & - & - & 75 & 120 \\
\hline n & 10 & 0,20 & - & - & - & - & - & 75 & 10 \\
\hline D & 10 & - & - & 0,5 & - & - & 0,35 & 75 & 180 \\
\hline
\end{tabular}

) jumlah bahan kimia dinyatakan sebagai persen terhadap pulp kering oven

${ }^{2}$ ) perkalian faktor ini dengan $K N$ dijadikan persentase bahan kimia terhadap pulp kering oven

Tabel 4. Kondisi pemutihan PP dan OPOP

\begin{tabular}{|c|c|c|c|c|c|c|c|c|}
\hline \multicolumn{9}{|c|}{ Proses PP } \\
\hline tahap & $\begin{array}{c}\text { konsistensi } \\
\% \\
\end{array}$ & $\begin{array}{c}\mathrm{NaOH} \\
\left.\%^{1}\right)\end{array}$ & $\begin{array}{l}\mathrm{O}_{2} \\
\mathrm{~atm}\end{array}$ & $\begin{array}{c}\text { EDTA } \\
\left.\%^{1}\right)\end{array}$ & $\begin{array}{c}\mathrm{H}_{2} \mathrm{O}_{2} \\
\left.\%{ }^{1}\right) \\
\end{array}$ & $\begin{array}{c}\mathrm{Na}_{2} \mathrm{SiO}_{3} \\
\left.\%{ }^{1}\right)\end{array}$ & $\begin{array}{l}\text { temp. } \\
{ }^{\circ} \mathrm{C}\end{array}$ & $\begin{array}{l}\text { waktu } \\
\text { menit }\end{array}$ \\
\hline $\mathbf{P}$ & 10 & 1 & $=$ & 0,5 & $4 ; 5 ; 6$ & 5 & 70 & 180 \\
\hline $\mathbf{P}$ & 10 & 1 & - & 0,5 & 2 & 5 & 70 & 180 \\
\hline \multicolumn{9}{|c|}{ Proses OPOP } \\
\hline 0 & 10 & 1 & 6 & & - & - & 100 & 60 \\
\hline $\mathbf{P}$ & 10 & - & - & 0,5 & $4 ; 5 ; 6$ & 0,5 & 70 & 180 \\
\hline 0 & 10 & 1 & 6 & & - & - & 100 & 60 \\
\hline $\mathbf{P}$ & 10 & - & $=$ & 0,5 & 2 & 0,5 & 70 & 180 \\
\hline
\end{tabular}


Walaupun pulp bahan pemutihan memiliki $\mathrm{KN}$ hampir sama (lihat Tabel 1), kandungan $\alpha$-selulosa pulp etanol putih selalu lebih rendah daripada pulp kraft putih. Hal ini mungkin dapat dijadikan indikasi bahwa sisa lignin dalam pulp kraft lebih mudah mengalami delignifikasi lanjut dan terlarut selama pemutihan.

Viskositas pulp putih (Gambar 3) terlihat sangat bervariasi, tetapi variasinya tidak mengikuti kecenderungan kandungan $\alpha$-selulosa. Misalnya viskositas pulp etanol putih OPOP terlihat sedikit lebih tinggi daripada pulp etanol putih PP, padahal kandungan $\alpha$-selulosa-nya lebih rendah. Umumnya viskositas pulp kraft etanol lebih rendah daripada pulp kraft putih.

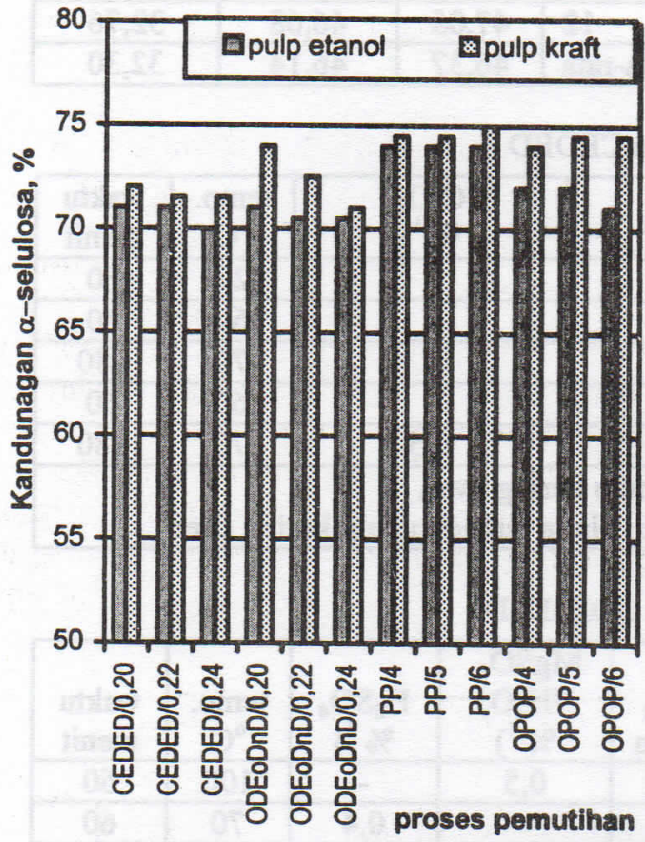

Gambar 2. Kandungan $\alpha$-selulosa pulp putih TKS dissolving pulp $=90 \%$

\section{Derajat putih}

Hasil pemutihan dengan proses konvensional yang menggunakan bahan kimia $\mathrm{Cl}_{2}$ atau $\mathrm{ClO}_{2}$ sangat memuaskan. Derajat putih pulp CEDED dan ODEoDnD mencapai 80-85\%GE, sesuai SNI untuk pulp kraft putih kayudaun $81 \%$ GE (Gambar 4). Sedangkan pemutihan dengan proses $T C F, \mathrm{PP}$ maupun OPOP, menghasilkan pulp putih dengan derajat putih hanya berkisar antara 40-55 \%GE, bahkan tidak mencapai persyaratan SNI kertas koran, $56 \% \mathrm{GE}$.

Evaluasi lebih lanjut menunjukkan bahwa rendemen pulp putih CEDED dan ODEoDnD juga sangat memuaskan, yaitu berkisar antara $80-98 \%$. Variasi jumlah khlor aktif (dinyatakan dengan faktor $0,20,0,22$ dan 0,24 sebagai pengali Kappa Number) dalam proses CEDED dan proses ODEoDnD ternyata tidak banyak mempengaruhi derajat putih pulp. Jadi proses-proses tersebut dapat dilaksanakan dengan jumlah $\mathrm{Cl}_{2}$ atau $\mathrm{ClO}_{2}$ seminimum mungkin yang dalam penelitian ini adalah $0,20 \mathrm{KN}$.

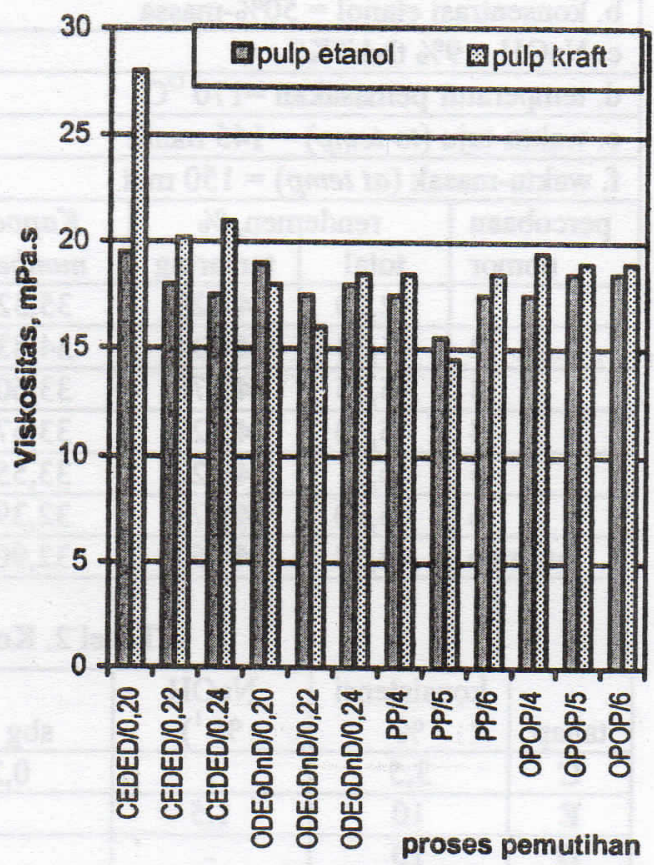

Gambar 3. Viskositas pulp putih TKS

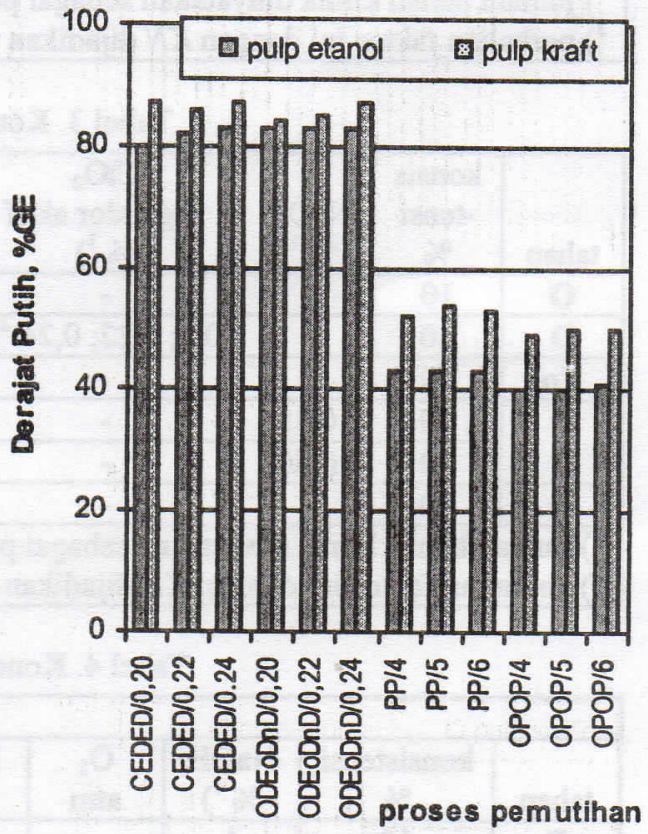

Gambar 4. Derajat putih pulp TKS; SNI pulp kraft putih $=81 \% \mathrm{GE}$; SNI kertas koran $=56$ $\% \mathrm{GE}$

Jika $\mathrm{ClO}_{2}$ dapat disediakan dengan mudah, pemutihan dengan proses ODEoDnD dapat diterapkan dalam industri pulp kecil mengingat proses $E C F$ ini lebih ramah lingkungan daripada yang menggunakan 
$\mathrm{Cl}_{2}$. Sampai saat ini, proses pemutihan dengan $\mathrm{ClO}_{2}$ masih digunakan secara komersial di Indonesia, misalnya:

a. tahapan $\mathrm{ODE}_{0} \mathrm{DD}$ di Riau Andalan Pulp and Paper di Pekanbaru

b. tahapan $\mathrm{ODE}_{\mathrm{OP}} \mathrm{DD}$ di Tanjung Enim Lestari di Palembang.

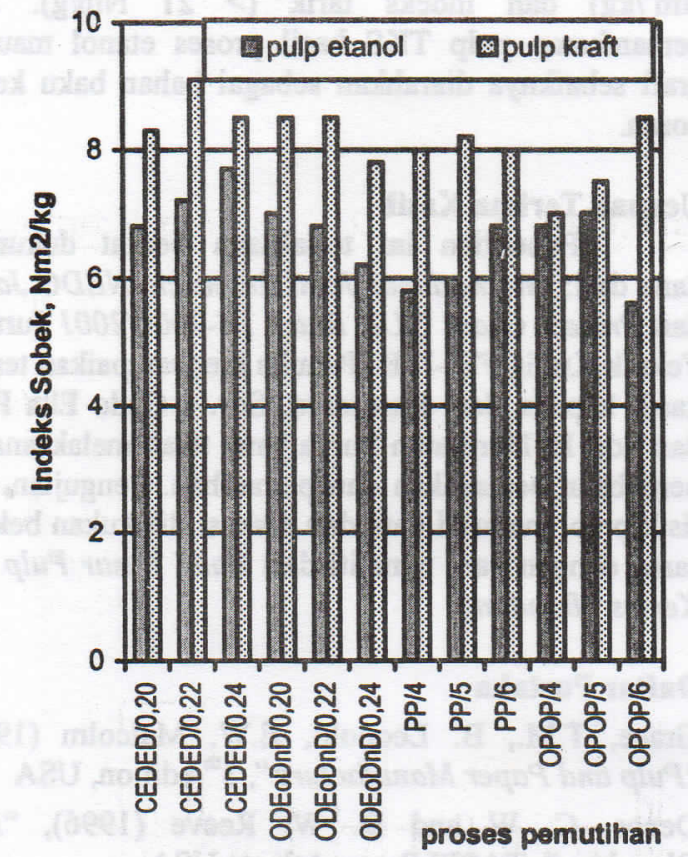

Gambar 5. Indeks sobek pulp putih TKS; pulp kraft putih kayudaun $=5,0$; pulp kraft putih kayujarum $=7,5$ kertas koran $=4,8$

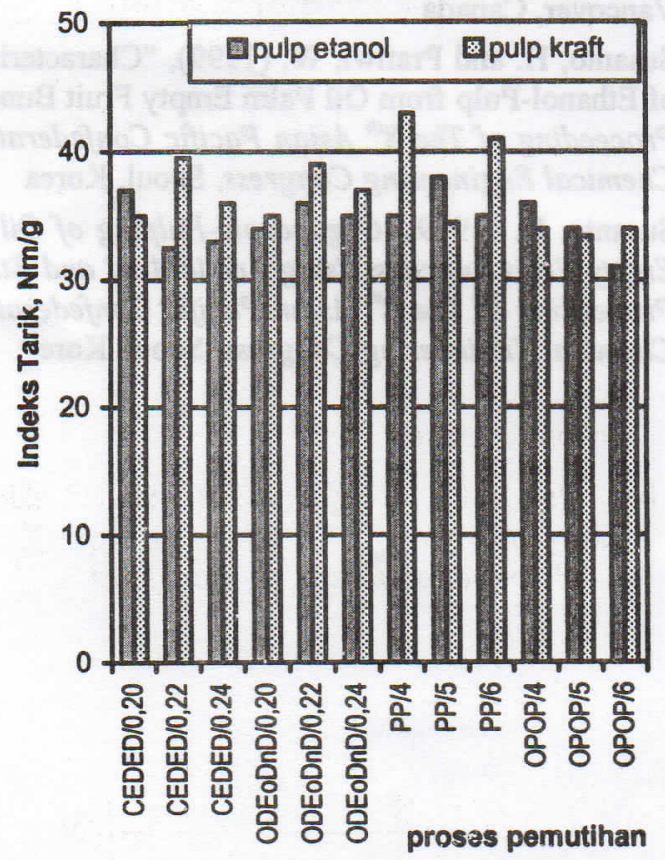

Gambar 6. Indeks tarik pulp putih TKS; pulp kraft putih kayudaun $=30$; pulp kraft putih kayu jarum $=50$; kertas koran $=22.5$

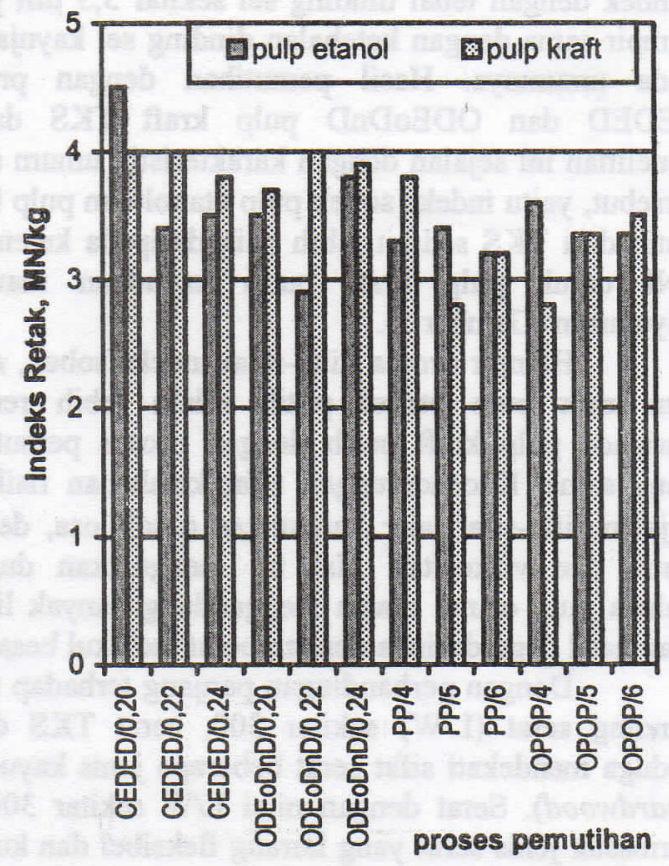

Gambar 7. Indeks retak pulp putih TKS; pulp kraft putih kayudaun $=2$; pulp kraft putih kayujarum $=4$

Penggunaan tahapan oksidasi dengan $\mathrm{O}_{2}$ ternyata tidak meningkatkan daya pemutihan proses OPOP dibandingkan dengan proses PP. Bahkan derajat putih pulp OPOP lebih rendah daripada pulp putih PP, demikian pula rendemennya. Jadi penggunaan $\mathrm{O}_{2}$ dalam proses pemutihan dengan peroksida ini sama sekali memperbaiki hasil pemutihan pulp TKS.

Dengan proses pemutihan yang sama, derajat putih pulp etanol putih selalu lebih rendah daripada pulp kraft putih. Pulping TKS dengan proses etanol kemungkinan selalu meninggalkan lignin dengan berat molekul besar yang relatif lebih sulit untuk dihilangkan lebih lanjut dalam proses pemutihan. Hal ini dapat dimengerti karena proses etanol memang lebih bersifat melarutkan lignin, sedangkan proses kraft lebih bersifat mendegradasi lignin dan kemudian melarutkan hasil-hasilnya.

Sifat fisik lembaran pulp putih

Ketahanan fisik merupakan salah satu kriteria dalam penentuan pemanfaatan pulp putih. Kekuatan fisik pulp ini sangat dipengaruhi oleh morfologi serat atau jenis bahan baku, pemasakan dan proses pemutihan [Smook, 1994]. Hasil pengujian lembaran pulp putih disajikan di Gambar-gambar 5, 6 dan 7 . 
Ketahanan sobek pulp banyak dipengaruhi oleh tebal dinding sel. Dinding sel tebal cenderung meningkatkan ketahanan sobek, tetapi menurunkan ketahanan tarik dan retak. Serat TKS adalah serat pendek dengan tebal dinding sel sekitar 3,5 $\mu \mathrm{m}$ yang hampir sama dengan ketebalan dinding sel kayujarum pada umumnya. Hasil pemutihan dengan proses CEDED dan ODEoDnD pulp kraft TKS dalam penelitian ini sejalan dengan karakteristik umum serat tersebut, yaitu indeks sobek pulp etanol dan pulp kraft putih dari TKS sedikit lebih baik daripada ketentuan SNI untuk pulp kraft putih kayudaun maupun kayujarum (Gambar 5).

Hampir semua nilai-nilai indeks sobek, retak dan tarik pulp etanol putih selalu lebih rendah daripada pulp kraft putih dengan proses pemutihan yang sama. Kecenderungan sifat ketahanan fisik ini sejalan sifat-sifat lain: kandungan $\alpha$-selulosa, derajat putih dan viskositas. Hal ini menguatkan dugaan bahwa pulp etanol masih mengandung banyak lignin atau hasil degradasinya dengan berat molekul besar.

Dengan perbandingan panjang terhadap tebal dinding serat (L/W) sekitar 300 , serat TKS dapat diduga mendekati sifat serat beberapa jenis kayudaun (hardwood). Serat dengan nilai L/W sekitar 300 ini termasuk jenis serat yang kurang fleksibel dan kurang memiliki daya ikatan antar serat, sehingga indeks tarik dan indeks retaknya relatif rendah. Sebagaimana terlihat dalam Gambar 5 dan Gambar 6, indeks tarik dan indeks retak pulp putih TKS umumnya memenuhi kualifikasi pulp kraft putih kayudaun menurut SNI yaitu berturut-turut $40,5 \mathrm{Nm} / \mathrm{g}$ dan $2,6 \mathrm{MN} / \mathrm{kg}$, tetapi jauh di bawah pulp kraft putih kayujarum.

\section{Kesimpulan dan Saran}

Walaupun penelitian ini ditujukan untuk mengkaji proses pemutihan, terungkap bahwa pemasakan TKS dengan proses etanol memerlukan kondisi yang lebih berat $\left(170^{\circ} \mathrm{C}\right.$ dan 3 jam) daripada proses kraft ( $150^{\circ} \mathrm{C}$ dan 2,5 jam). Kondisi proses etanol ini perlu diperbaiki untuk meningkatkan daya tariknya sebagai proses ramah lingkungan. Untuk industri pulp skala kecil, temperatur dan tekanan proses harus dapat diturunkan, walaupun mungkin perlu diimbangi dengan penambahan waktu pemasakan.

Kualitas pulp etanol putih umumnya sedikit di bawah pulp kraft putih, yaitu: indeks sobek 6,5 vs $8,5 \mathrm{Nm}^{2} / \mathrm{kg}$ dan indeks retak 3,5 vs $3,7 \mathrm{MN} / \mathrm{kg}$, sedangkan indeks tarik kedua jenis pulp tidak terlalu berbeda yaitu sekitar $34 \mathrm{Nm} / \mathrm{g}$. Ketahanan fisik pulp TKS ini sedikit di bawah spesifikasi pulp kraft putih kayudaun, tetapi jauh di bawah spesifikasi pulp kraft putih kayu jarum.

Derajat putih pulp etanol hasil pemutihan dengan tahapan PP dan OPOP (TCF) hanya sekitar 49
$\% \mathrm{GE}$, sedangkan hasil pemutihan tahapan CEDED dan ODEoDnD $(E C F)$ dapat mencapai 80-84\%GE dan memenuhi spesifikasi pulp kraft putih kayudaun $81 \%$ GE.

Pulp putih. TKS hasil pemutihan dengan proses CEDED dan ODEoDnD (Elemental Chlorine Free) memenuhi spesifikasi kertas koran dalam hal derajat putih (> $57 \% \mathrm{GE})$, indeks sobek (> 4,35 $\mathrm{Nm}^{2} / \mathrm{kg}$ ) dan indeks tarik ( $\left.>21 \mathrm{Nm} / \mathrm{g}\right)$. Jadi pemanfaatan pulp TKS hasil proses etanol maupun kraft sebaiknya diarahkan sebagai bahan baku kertas koran.

\section{Ucapan Terima Kasih}

Penelitian ini terlaksana berkat dukungan dana dari: International Joint Research, NEDO Japan dan Project Grant QUE Batch III-2000/2001 Jurusan Teknik Kimia FTI-ITB. Penulis menyampaikan terima kasih kepada Sdr. Rusmanto, Sdr. I Gede Eka Panji dan Sdr. R. Dorojatun Surya yang telah melaksanakan percobaan pemasakan dan pemutihan. Pengujian sifat fisik pulp, evaluasi data dan diskusi dilakukan bekerja sama dengan para peneliti dari Balai Besar Pulp dan Kertas, Bandung.

\section{Daftar Pustaka}

Grace, T.M., B. Leopold, E.W. Malcolm (1989), "Pulp and Paper Manufacture", $3^{\text {th }}$ edition, USA

Dence, C. W and D. W. Reeve (1996), "Pulp Bleaching", TAPPI Press, Atlanta USA

Petty, G. (1989), "Canadians Pioneer a Small-scale Pulp Mill", Paper Technology, February

Smook, G.A. (1994), "Handbook for Pulp and Paper Technology", $2^{\text {nd }}$ Editian, Angus Wilde Publications, Vancover, Canada

Susanto, H. and Pratiwi, W. (1999), "Characterization of Ethanol-Pulp from Oil Palm Empty Fruit Bunches", Proceeding of The $8^{\text {th }}$ Asian Pacific Confederation of Chemical Engineering Congress, Seoul, Korea

Susanto, H. (1999), Organosolv-Pulping of Oil Palm Empty Fruit Bunches Using Acetic Acid and Ethanol, Proceeding of The $8^{\text {th }}$ Asian Pacific Confederation of Chemical Engineering Congress, Seoul, Kore 